\title{
Implementation of Green Economy Instruments at Food Industry Enterprises on the Basis of Implementation of Innovative Projects
}

\author{
Sergey Tkachev, Konstantin Kolotyrin*, and Mikhail Eryushev \\ Saratov State Agrarian University named after N.I. Vavilova, Theater Square 1, Saratov 410012 \\ Russian Federation
}

\begin{abstract}
The problems associated with development of green economy instruments at food industry enterprises are considered. On the basis of the analysis, it is concluded that insufficient attention is paid to environmental problems in the food industry in Russia. Introduction of modern equipment is carried out on the basis of implementation of innovative projects, where "green" investment is negligible. An analysis of the structure of investment in "green technologies" showed that these are mainly private investment resources, and government funding is minimal. It is concluded that it is necessary to develop instruments for financing innovative projects to introduce mechanisms of a "green" economy in the food industry. In order to stimulate the implementation of innovative environmental projects at food industry enterprises, such modern tools as public-private partnerships, insurance, concessional lending, and etc. are offered. As a result of the offered approaches to implementation of innovative projects based on a "green economy" at food industry enterprises, the environmental efficiency of the food industry will increase, as well as significantly reduce costs due to introduction of resource-saving technologies.
\end{abstract}

\section{Introduction}

At the moment, the processing and food industry of the Russian Federation is the leading sector of the agro-industrial complex, and the share of the domestic market for products of the processing industry accounts for at least $95 \%$ of the food consumed in our country.

Currently, the food industry in Russia includes about 30 industries and more than 60 types of various industries, including 22 thousand enterprises located in the territory of the Russian Federation, with the number of employees exceeding 2 million people. The main branches of the food industry are meat; fish, dairy, bakery, flour and fat-and-oil [1].

Nevertheless, the existing rates of development of the food industry lead to significant environmental problems, especially acutely manifested in recent years. The main environmental problems include the following:

- a large amount of waste generated;

*Corresponding author: kpk75@mail.ru 
- low level of resource saving;

- occurrence of significant accumulated environmental damage;

- low level of environmental investments;

- outdated environmentally hazardous technologies for processing agricultural raw materials;

- insufficient use of secondary resources as raw materials.

It shall be noted that the environmental problems of the processing industry of the agroindustrial complex, in most cases, are associated with the generated waste, which pollute the land and water bodies, and also lead to a deterioration in the sanitary and epidemiological situation. Each year, these enterprises generate about 40 million tons of byproducts and waste, while a small part of them is involved in the secondary circulation [2]. Wherein, according to expert estimates, given the current situation with waste generation at food and processing industries, at least $93 \%$ of waste can be used, which is approximately 32 million tons of finished products for 130 items [3].

Basically, the secondary resources of the food and processing industry of the agroindustrial complex are directed to livestock complexes as feed and additives. According to some reports, $70 \%$ of the total volume of secondary resources goes to animal feed, about $20 \%$ is processed with a low processing depth, and $7 \%$ of this type of resources must be buried both at authorized landfills and at unauthorized dumps $[4,5]$.

It is necessary to consider the fact that the maximum amount of hazardous waste is generated in the meat processing industries.

A number of problems associated with the low level of material and technical support of many enterprises processing agricultural raw materials, poorly developed infrastructure for storage and transportation of raw materials and finished products does not allow for a comprehensive processing of raw materials, which leads to large losses of resources, reduces the safety characteristics and quality of products, and increases the negative environmental impact.

Many problems in the food and processing industry of the agro-industrial complex are associated with the renewal of the material and technical base, which leads to high costs for energy resources [6]. As a result, the depth of processing of raw materials decreases, the transition to a resource-and-energy-saving way of enterprises in the food and processing industries of the agro-industrial complex slows down, the environmental load on the environment increases, and access to foreign markets becomes more difficult [7].

Sustainable development of the food and processing industry also looks bad in terms of energy costs. Namely, the unit costs in the cost of production of food industry enterprises are at least $3.1 \%$. Wherein, in developed countries this indicator is at the level of $1.7 \%$, in developing countries $-2.5 \%$, in the BRICS countries $-1.9 \%$ [8].

In this regard, it is advisable to consider the functioning of the food industry from the standpoint of a "green" economy, which makes it possible to effectively use modern environmental approaches in their activities.

\section{Methods}

Based on the definition of a green economy, given in the United Nations Environment Program (UNEP), this economy shall be aimed at improving the well-being of the population and ensuring social justice, as well as minimizing negative consequences for environment, based on the principles shown in Figure 1. 


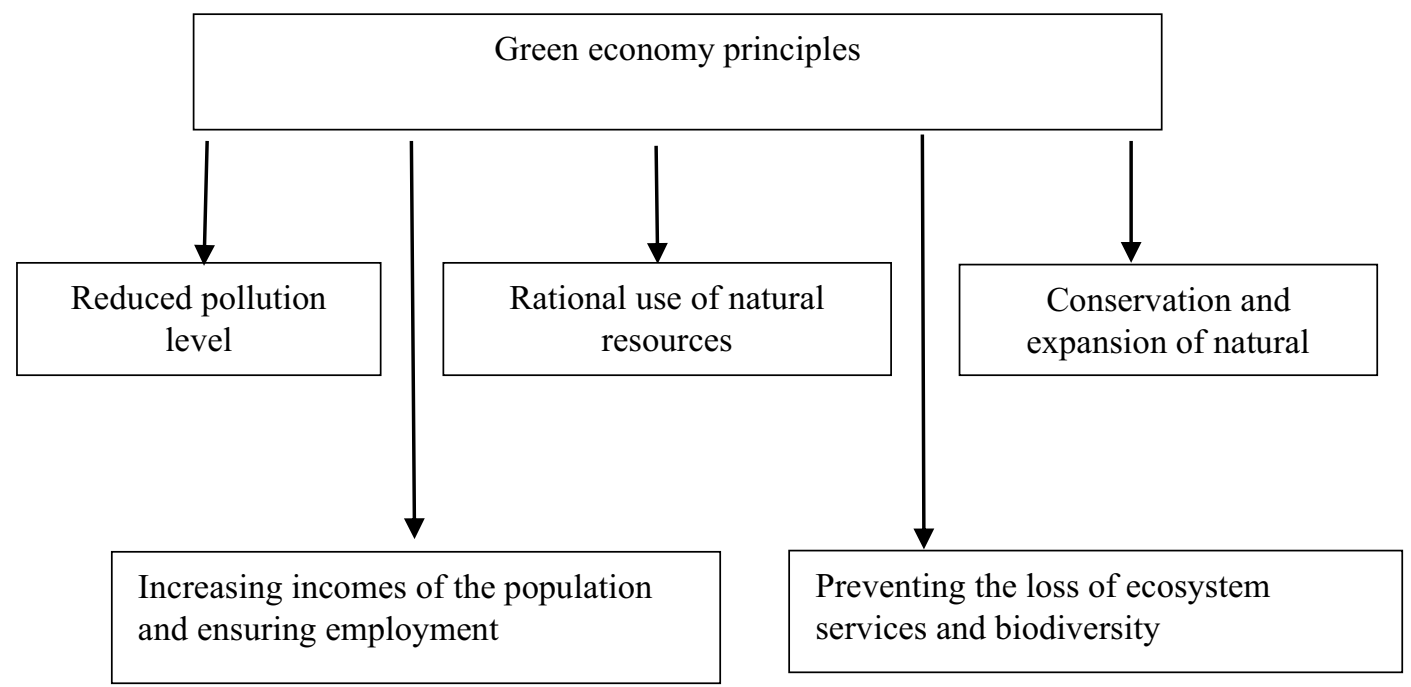

Fig. 1. Basic principles of the green economy.

Considering the basic principles of the "green" economy in the framework of the functioning of food industry enterprises, it can be noted that the main ones will be reducing the level of pollution using resource-saving technologies, analyzing the life cycle of products, considering the requirements of environmental safety.

As a rule, in their activities, food industry enterprises are guided by economic and financial interests, while environmental and social trends are ignored, or are considered insignificant $[9,10]$. In this regard, the "green" economy will change the existing paradigm, and ensure the transition to sustainable development of food industry enterprises [11].

It is obvious that for the effective use of the principles of the "green" economy by food industry enterprises, it is necessary to attract investors who are certainly interested in obtaining the expected rate of return and guarantees for the invested resources [12-13].

At the moment, investments in the green economy are very insignificant, and statistics on this indicator in the food industry are inaccurate. The study of the structure of "green" investments showed that in Europe and the United States these are mostly state investors, while in Russia, the main investor is the commercial sector, but these investments are very insufficient and do not solve the existing environmental problems in the food industry [14, $15]$.

Introduction of innovative projects related to the "green" economy would also allow solving the problems of environmental improvement of the industry, but these projects are practically not being implemented, as evidenced by the data in Table 1 .

As can be seen from the table compiled on the basis of statistical data, there are no direct investments in environmentally oriented innovation projects. It can be assumed that in such areas as "Costs for technological innovation" and "Number of developed advanced technologies", the costs of "green" innovation projects can be taken into account, but their share is quite low. 
Table 1. Innovation and advanced manufacturing technology.

\begin{tabular}{|c|c|c|c|c|c|c|c|c|c|}
\hline Indicators & 2010 & 2011 & 2012 & 2013 & 2014 & 2015 & 2016 & 2017 & 2018 \\
\hline \multicolumn{10}{|c|}{$\begin{array}{c}\text { Innovative activity of organizations (the proportion of organizations that carried out technological, } \\
\text { organizational, marketing innovations), } \%\end{array}$} \\
\hline $\begin{array}{l}\text { In general } \\
\text { for the } \\
\text { economy }\end{array}$ & 9.5 & 10.4 & 10.3 & 10.1 & 9.9 & 9.3 & 8.4 & 8.5 & $\ldots$ \\
\hline $\begin{array}{l}\text { Manufactur } \\
\text { e of food } \\
\text { products, } \\
\text { including } \\
\text { beverages }\end{array}$ & 11.6 & 11.8 & 11.9 & 11.0 & 12.5 & 12.2 & 12.2 & $\begin{array}{l}13.0 / \\
10.6^{*}\end{array}$ & $\cdots$ \\
\hline \multicolumn{10}{|c|}{ Costs for technological innovations of organizations, $R U B \mathrm{mln}$} \\
\hline $\begin{array}{l}\text { In general } \\
\text { for the } \\
\text { economy }\end{array}$ & $\begin{array}{c}40080 \\
3.8\end{array}$ & $\begin{array}{c}733816 \\
.0\end{array}$ & $\begin{array}{c}904560 \\
.8\end{array}$ & $\begin{array}{c}111242 \\
9.2\end{array}$ & $\begin{array}{c}121189 \\
7.1\end{array}$ & $\begin{array}{c}120363 \\
8.1\end{array}$ & $\begin{array}{c}128459 \\
0.3\end{array}$ & $\begin{array}{l}140498 \\
5.3\end{array}$ & $\begin{array}{c}147282 \\
2.3\end{array}$ \\
\hline $\begin{array}{l}\text { Manufactur } \\
\text { e of food } \\
\text { products, } \\
\text { including } \\
\text { beverages }\end{array}$ & 7954.6 & $\begin{array}{c}11830 . \\
8\end{array}$ & $\begin{array}{c}16183 . \\
1\end{array}$ & $\begin{array}{l}28950 . \\
1\end{array}$ & 22592.1 & 16215.7 & $\begin{array}{l}22907 . \\
6\end{array}$ & $\begin{array}{c}43879.2 \\
/ \\
4338.7 *\end{array}$ & $\begin{array}{c}40790.2 \\
/ \\
16710.4 \\
*\end{array}$ \\
\hline \multicolumn{10}{|c|}{ Share of organizations implementing technological innovations, \% } \\
\hline $\begin{array}{l}\text { In general } \\
\text { for the } \\
\text { economy }\end{array}$ & 7.9 & 8.9 & 9.1 & 8.9 & 8.8 & 8.3 & 7.3 & 7.5 & $\cdots$ \\
\hline $\begin{array}{l}\text { Manufactur } \\
\text { e of food } \\
\text { products, } \\
\text { including } \\
\text { beverages }\end{array}$ & 9.5 & 9.6 & 9.3 & 9.0 & 10.3 & 10.2 & 10.0 & $\begin{array}{c}10.8 / \\
9.0^{*}\end{array}$ & $\cdots$ \\
\hline \multicolumn{10}{|c|}{ Volume of innovative goods, works, services, $m \ln$ rubles } \\
\hline $\begin{array}{l}\text { In general } \\
\text { for the } \\
\text { economy }\end{array}$ & $\begin{array}{c}124371 \\
2.5\end{array}$ & $\begin{array}{c}210674 \\
0.7\end{array}$ & $\begin{array}{c}287290 \\
5.1\end{array}$ & $\begin{array}{c}350786 \\
6.0\end{array}$ & $\begin{array}{c}3579923 \\
.8\end{array}$ & $\begin{array}{c}3843428 \\
.7\end{array}$ & $\begin{array}{c}4364321 \\
7\end{array}$ & $\begin{array}{c}416699 \\
8.7\end{array}$ & $\begin{array}{c}451627 \\
6.4\end{array}$ \\
\hline $\begin{array}{l}\text { Manufactur } \\
\text { e of food } \\
\text { products, } \\
\text { including } \\
\text { beverages }\end{array}$ & $\begin{array}{c}117788 \\
.3\end{array}$ & $\begin{array}{c}116193 . \\
1\end{array}$ & $\begin{array}{c}113182 . \\
7\end{array}$ & $\begin{array}{c}127817 . \\
4\end{array}$ & $\begin{array}{c}180282 . \\
7\end{array}$ & $\begin{array}{c}209289 . \\
3\end{array}$ & 236948.0 & $\begin{array}{c}291811 . \\
8 / \\
21580.1 \\
*\end{array}$ & $\begin{array}{c}272304 . \\
3 / \\
14149.4 \\
*\end{array}$ \\
\hline \multicolumn{10}{|c|}{ The number of developed advanced production technologies, units } \\
\hline $\begin{array}{l}\text { In general } \\
\text { for the } \\
\text { economy }\end{array}$ & 864 & 1138 & 1323 & 1429 & 1409 & 1398 & 1534 & 1402 & 1565 \\
\hline $\begin{array}{l}\text { Manufactur } \\
\text { e of food } \\
\text { products, } \\
\text { including } \\
\text { beverages }\end{array}$ & 9 & 15 & 29 & 15 & 18 & 15 & 16 & $16 / 7^{*}$ & $24 / 10^{*}$ \\
\hline \multicolumn{10}{|c|}{ The number of developed advanced production technologies new for Russia, units } \\
\hline $\begin{array}{l}\text { In general } \\
\text { for the } \\
\text { economy }\end{array}$ & 762 & 1028 & 1188 & 1276 & 1245 & 1223 & 1342 & 1212 & 1384 \\
\hline
\end{tabular}




\begin{tabular}{|c|c|c|c|c|c|c|c|c|c|}
\hline Indicators & 2010 & 2011 & 2012 & 2013 & 2014 & 2015 & 2016 & 2017 & 2018 \\
\hline $\begin{array}{l}\text { Manufactur } \\
\text { e of food } \\
\text { products, } \\
\text { including } \\
\text { beverages }\end{array}$ & 9 & 15 & 26 & 12 & 16 & 14 & 32 & $16 / 7^{*}$ & $22 / 10^{*}$ \\
\hline \multicolumn{10}{|c|}{ The number of fundamentally new developed advanced production technologies, units } \\
\hline $\begin{array}{l}\text { In general } \\
\text { for the } \\
\text { economy }\end{array}$ & 102 & 110 & 135 & 153 & 164 & 175 & 192 & 190 & 181 \\
\hline $\begin{array}{l}\text { Manufactur } \\
\text { e of food } \\
\text { products, } \\
\text { including } \\
\text { beverages }\end{array}$ & $\cdots$ & ... & 3 & 3 & 2 & 1 & 1 & $\ldots / \ldots *$ & $2 / \ldots *$ \\
\hline \multicolumn{10}{|c|}{ The number of advanced production technologies used, units } \\
\hline $\begin{array}{l}\text { In general } \\
\text { for the } \\
\text { economy }\end{array}$ & $\begin{array}{c}20333 \\
0\end{array}$ & 191650 & 191372 & 193830 & 204546 & 218018 & $\begin{array}{c}23238 \\
8\end{array}$ & 240054 & 254927 \\
\hline $\begin{array}{l}\text { Manufactur } \\
\text { e of food } \\
\text { products, } \\
\text { including } \\
\text { beverages }\end{array}$ & 11223 & 11282 & 12231 & 12697 & 13114 & 14535 & 15059 & $\begin{array}{c}13021 / \\
3362 *\end{array}$ & $\begin{array}{c}14264 / \\
3425^{*}\end{array}$ \\
\hline
\end{tabular}

* food production/beverage production

The problem of the low level of financing of "green" innovations is associated not only with insufficient state funding, but also with the lack of guarantees for investment investments. Wherein, it is rather difficult to assess the effectiveness of innovative projects in the "green" economy, due to the lack of information and statistical data. It is also pertinent to note that natural benefits are not always objectively assessed, and the investor, when implementing innovative projects, will use commercial performance indicators, for example, NPV, IR, IRR and etc.

\section{Results}

Based on the world experience in achieving the environmental and economic efficiency of enterprises for processing agricultural products, it can be noted that its achievement is precisely related to the optimal use of the available resources of these enterprises, through use of modern innovative processing technologies.

It shall be borne in mind that the low level of funding for projects aimed at acquiring innovative technologies makes it difficult to use green economy areas aimed at reducing the negative environmental impact of food and processing industries, as well as improving resource saving indicators.

In order to increase the investment attractiveness of projects aimed at introducing "green" technologies in the food industry, it is necessary to use tools that provide incentives for these projects for investment from various sources. Not only private organizations, but also government agencies can act as investors in innovative projects. Obviously, the main focus of the investment will be the environmental performance of data, as well as the economic and commercial dimensions.

Existing approaches to managing environmental processes include the following areas:

- direct regulation, which implies public administration, including regulatory impact, oversight functions, direct intervention, and etc.; 
- stimulating approaches to the management of environmental processes based on the optimal combination of public administration and market instruments;

Wherein, there are several mechanisms of environmental management that are stimulating, hard and soft. Therefore, the compensating mechanism is based on general restrictive approaches and provides for compensation for negative environmental damage, unfortunately, significantly limiting development opportunities. At present, this mechanism for regulating environmental management is predominant and does not allow the development of investment processes with the aim of introducing new technologies at food industry enterprises.

The tough mechanism of environmental management is associated with use of tough legal, tax, credit and penal policies, and is based solely on saving resources, and not on their efficient use, which is contrary to the principles of economic growth.

Use of an incentive mechanism based on use of a large number of market instruments and government forms of support will increase interest in investing in environmentally friendly projects related to the modernization of fixed assets in the food industry.

Public-private partnerships, preferential lending, insurance and preferential taxation, presented in the figure, can be used as tools for implementation of the stimulating direction of environmental management in the food industry.

Thus, use of public-private partnerships in the modernization of fixed assets at food and processing industry enterprises will increase investment attractiveness and attract additional sources of financing through various government projects and programs, within the framework of state equity participation. Transfer of some of the management functions from the state to private individuals will also contribute to increasing environmental efficiency in the activities of food and processing industries. Within the framework of public-private partnership projects, it is possible to make full use of market mechanisms, which is also attractive to investors.

The role of state participation in implementation of public-private partnership projects will be to establish the "rules of the game" in order to increase the environmental efficiency of agro-industrial complex processing enterprises. In the case of the development of projects for introduction of the best technologies, state participation can be expressed in funding scientific research in this area, as well as in supporting the popularization of innovative technologies in the food industry.

Use of concessional lending as a tool to support the development of environmentally friendly technologies at food industry enterprises. Namely, when purchasing equipment that meets the requirements of environmental safety, it is advisable to issue a loan at a reduced rate, and compensate for the difference within the framework of the public-private partnership described above. When implementing this type of lending, the bank's interest will be expressed in additional guarantees from the state. Similarly, it is possible to use leasing, which allows to purchase equipment on favorable terms for the customer. Existing government programs in the field of leasing allow to purchase environmentally friendly equipment on favorable terms

Use of insurance instruments within implementation of environmentally oriented projects in the food industry will not only reduce risks for potential investors, but also reduce the likelihood of an adverse event, for example, equipment malfunctions or noncompliance with its declared characteristics. If necessary, environmental risks can also be insured, in the case of the requirements of the state participant in the project.

Preferential taxation is also an effective incentive measure to attract investment in the renewal of fixed assets in order to reduce the environmental risks of agricultural processing enterprises. Particular interest, in this case, will be on the possibility of using accelerated depreciation of equipment, which will ensure the environmental safety of production processes in the food industry, especially since this mechanism is reflected at the legislative 
level. As a result, the investor will be able to reduce the taxable base and receive additional profit.

\section{Discussion}

Implementation of the above approaches to implementation of innovative projects in the food industry related to the "green economy" will be fraught with a number of difficulties, including the following:

- insufficient government support for "green" innovations;

- lack of incentives for agricultural producers to implement environmental projects and programs;

- a long payback period for innovative projects related to the "green" economy;

- high level of risks of innovative environmental projects, and unwillingness to insure them;

- expensive innovative equipment that meets modern environmental standards;

- lack of an effective system for monitoring the implementation of projects related to the "green" economy.

\section{Conclusion}

Therefore, on the basis of the above, we can conclude that introduction of green economy instruments at food industry enterprises is an urgent need. Firstly, this is due to the solution of the main task related to environmental protection based on the reduction of harmful emissions and waste pollution, and secondly, the introduction of environmental technologies will significantly reduce costs and increase the competitiveness of products of food industry enterprises.

Introduction of innovative projects based on the "green" economy at food industry enterprises is possible only with the active participation of government agencies, expressed in the provision of benefits and subsidies, compensation for interest on loans and leasing transactions, as well as reducing the tax burden on investors.

\section{References}

1. S.P. Kalashnikova, K.P. Kolotyrin, Organizacionno-ekonomicheskie instrumenty bezopasnogo upravleniya othodami myasopererabatyvayushchih predpriyatij (2017)

2. Federal'nyj zakon ot 10.01.2002 № 7-fz «Ob ohrane okruzhayushchej sredy» (2018)

3. Strategiya ekologicheskoj bezopasnosti Rossijskoj Federacii na period do 2025 goda, utv. Ukaz Prezidenta Rossijskoj Federacii ot 19 aprelya 2017 goda №176

4. S. N. Bobylev, A. SH. Hodzhaev, Ekonomika prirodopol'zovaniya (2007)

5. L.G. Mel'nik, L. Kury, Social'no-ekonomicheskij potencial ustojchivogo razvitiya (2007)

6. I.L. Voronikov, K.P. Kolotyrin, O.V. Vlasova, Sistema sovershenstvovaniya upravleniya biologicheskimi othodami na osnove mekhanizmov gosudarstvennochastnogo partnerstva i ekologicheskogo strahovaniya (2014)

7. Navstrechu «zelenoj ekonomike»: puti k ustojchivomu razvitiyu i iskoreneniyu bednosti (YUNEP, 2011)

8. I.L. Voronikov, K.P. Kolotyrin, O.V. Vlasova, Economical annals (2014) 
9. The Green Book: Appraisal and Evaluation in Central Government, HM Treasury (London, 2003)

10. Towards a Green Economy in Europe: EU Environmental Policy Targets and Objectives 2010-2050, European Environment Agency Report (2013)

11. P. Sukhdev, H. Wittmer, D. Miller, Nature in the Balance: The Economics of Biodiversity (Oxford, Oxford University Press, 2014)

12. The Global Green Economy Index (GGEI) 2016: Measuring National Performance in the Green Economy (2016)

13. Green Bonds Principles, ICMA (2015)

14. S. Kidney, B. Sonerud, P. Oliver, Growing a green bonds market in China. Key recommendations for policymakers in the context of China's changing financial landscape (2015)

15. J. Spector, CityLab (2015)

16. D. Turner, Institutional investor (2015) 